\section{THU0267 GASTROINTESTINAL INVOLVEMENT IN SPONDYLOARTHRITIS IS NOT ALL IBD: INCREASED RISK OF DIVERTICULITIS WITH LONGER DISEASE DURATION IN THE ASAS-COMOSPA COHORT}

M.H. Derakhshan ${ }^{1}$, N. Goodson ${ }^{2}$, J. Packham ${ }^{3}$, R. Sengupta ${ }^{4}$, A. Molto ${ }^{5}$, H. MarzoOrtega $^{6}$, S. Siebert ${ }^{1}$, on behalf of BRITSpA and the ASAS-COMOSPA investigators. ${ }^{1}$ Institute of Infection, Immunity and Inflammation, University of Glasgow, Glasgow, ${ }^{2}$ Academic Rheumatology Department, University of Liverpool, Liverpool; ${ }^{3}$ Haywood Rheumatology Centre, Keele University, Keele; ${ }^{4}$ Royal National Hospital for Rheumatic Diseases, Bath, UK; ${ }^{5}$ Hôpital Cochin, Paris Descartes University, Paris, France; ${ }^{6}$ NIHR LBRC, Leeds Teaching Hospitals Trust and LIRMM, University of Leeds, Leeds, UK

Background: Inflammatory bowel disease (IBD) is an established extra-articular manifestation of Spondyloarthritis (SpA). The association of SpA with other gastrointestinal and hepatic comorbidities is less well known.

Objectives: To examine the relationship between $\mathrm{SpA}$ disease duration and gastrointestinal comorbidities other than IBD.

Methods: ASAS-COMOSPA is a large global cross-sectional study comprising 3984 patients with SpA. We evaluated the association between "SpA disease duration" (defined in 5 year blocks) and upper gastrointestinal ulcers, hepatitis B (HBV), hepatitis $\mathrm{C}(\mathrm{HCV})$ and diverticulitis. Binary logistic regression models were created, adjusted for age, sex, BMI, smoking, alcohol, NSAIDs, DMARDs, biologics, steroids and IBD history. Subgroup analysis was performed, stratified by peripheral and/or axial joint involvement.

Results: The data of 3923 patients $(64.9 \%$ male) were available for analysis, $5.3 \%$ of whom had a history of IBD. The self-reported prevalence of other gastrointestinal conditions was: upper gastrointestinal ulcers $10.7 \%$; viral hepatitis $4.7 \%$ and diverticulitis $1.5 \%$, with significant geographic variation. "SpA disease duration" was not associated with the occurrence of the upper gastrointestinal ulcers (OR=0.98, 95\% Cl: $0.92-1.05)$, HBV (OR=0.43, 95\% Cl: $0.28-0.67)$ or $\mathrm{HCV}$ $(\mathrm{OR}=0.27,95 \% \mathrm{Cl}: 0.11-0.62)$. In contrast, the risk of diverticulitis was significantly increased by "SpA disease duration" (OR=1.14, 95\% Cl: 1.01-1.29); increased risk of $14 \%$ for every 5 years of disease duration) across the entire cohort, after adjustment for potential confounders, including age. Confounding variables showing significant association with diverticulitis were current age $(\mathrm{OR}=1.06,95 \% \mathrm{Cl}: 1.04-1.08)$ and high alcohol ( 33 units/day) intake (OR=3.84, $95 \% \mathrm{Cl}: 1.62-9.07$ ) but not medication history (table 1). Subgroup analyses revealed stronger association of $\mathrm{SpA}$ disease duration with diverticulitis in those with axial $(\mathrm{OR}=1.24,95 \% \mathrm{Cl}: 1.08-1.42)$ than those with peripheral $(\mathrm{OR}=1.12$, 95\% Cl: 0.98-1.29) SpA disease.

Abstract THU0267 - Table 1. Association between diverticulitis and SpA disease duration

\begin{tabular}{|c|c|c|c|}
\hline & $\begin{array}{c}p \\
\text { value }\end{array}$ & OR & $\begin{array}{l}95 \% \mathrm{Cl} \text { for } \\
\text { OR }\end{array}$ \\
\hline $\begin{array}{l}\text { SpA Disease Duration (5 y } \\
\text { blocks) }\end{array}$ & 0.032 & 1.14 & $1.01-1.29$ \\
\hline Delay in SpA Diagnosis & 0.477 & 1.01 & $0.98-1.04$ \\
\hline Age (year) & $<0.001$ & 1.06 & $1.04-1.08$ \\
\hline Gender (ref: Female) & 0.062 & 0.57 & $0.31-1.03$ \\
\hline Current BMI & 0.965 & 1.00 & $0.95-1.05$ \\
\hline Smoking (pack-year) & 0.354 & 1.01 & $0.99-1.02$ \\
\hline Alcohol (ref: Never) & 0.022 & & \\
\hline Ex-drinker & 0.731 & 1.25 & $0.35-4.51$ \\
\hline Current, $<3$ Units & 0.132 & 1.66 & $0.86-3.23$ \\
\hline Current, ${ }^{3} 3$ Units & 0.002 & 3.84 & $1.62-9.07$ \\
\hline Ever use of NSAIDs & 0.816 & 0.90 & $0.37-2.21$ \\
\hline Ever use of Steroids & 0.380 & 1.30 & $0.73-2.31$ \\
\hline Ever use of DMARDs & 0.805 & 0.93 & $0.51-1.69$ \\
\hline Ever use of Biologics & 0.613 & 1.16 & $0.66-2.04$ \\
\hline History of IBD & 0.904 & 1.07 & $0.37-3.12$ \\
\hline
\end{tabular}

Conclusions: Patients with SpA have a number of gastrointestinal comorbidities, including increased risk of diverticulitis with increased SpA disease duration, highest in those with axial disease. The reasons for this association are unclear and warrant further investigation. Diverticulitis should be considered, in addition to $\mathrm{IBD}$, when patients with $\mathrm{SpA}$ present with lower gastrointestinal symptoms.

Disclosure of Interest: None declared

DOI: 10.1136/annrheumdis-2018-eular.5479

\section{THU0268 THE FREQUENCY OF JUVENILE SPONDYLOARTHROPATHIES IN CHILDHOOD FAMILLIAL MEDITERRANEAN FEVER}

E. Ozer, D. Seker, H.E. Taner, A. Adrovic, S. Sahin, O. Koker, K. Barut, O. Kasapcopur. Pediatric Rheumatology, Istanbul University, Cerrahpasa Medical School, Istanbul, Turkey

Background: Familial Mediterranean fever (FMF) is the most common monogenic autoinflammatory disease characterised with fever, recurrent episodes of self-limiting polyserositis and arthritis. FMF arthritis is generally acute monoarthritis especially in the larger joints of the lower extremities, healing without a sequelae. However some of the patients develop different type of chronic arthritis, predominantly oligoarticular juvenile idiopathic arthritis (JIA) and juvenile pondyloarthropathies (JSpA). Studies on JSpA among childhood FMF patients are spare.

Objectives: To evaluate frequency of JSpA in a large childhood FMF cohort. Furthermore, we aimed to define main characteristics of JSpA among childhood FMF patients.

Methods: A total of 320 juvenile FMF patients were blindly questioned according to recently proposed criteria for JSpA by 3 researchers (EO, DS, ET) that were previously educated for FMF and JSpA. A standardised case report form was prepared and completed for each patient. This form was including demographic data, clinical features, MEFV mutation and treatment. Patients fulfilled the JSpA criteria and were classified as probable JSpA. Afterwards, an expert in paediatric rheumatology (OK) reevaluated the classified patients and some of them were confirmed to be a definite while some of them were accepted as potential JSpA patients.

Results: As a result, 37 patients $(11.5 \%)$ were initially classified as potential JSpA. Furthermore, $32(10 \%)$ of them were accepted as definite and $5(1.5 \%)$ patients as probable JSpA in childhood FMF. Demographic, clinical and treatment data of definitive JSPA patients are shown in Table I. The most frequent MEFV mutation among JSPA patients was M694V (63.33\%).

Table I. Demographic, clinical and genetic features of childhood FMF patients.

\begin{tabular}{|c|c|c|c|c|}
\hline & $\begin{array}{l}\text { FMF + } \\
\text { Definite } \\
\text { JSPA }\end{array}$ & $\begin{array}{c}\text { FMF + } \\
\text { Probable } \\
\text { JSPA }\end{array}$ & $\begin{array}{c}\text { FMF patients } \\
\text { without JIA and } \\
\text { JSpA }\end{array}$ & $\begin{array}{l}\text { FMF+JIA (except } \\
\text { ERA or JSpA) }\end{array}$ \\
\hline Patients, $\mathrm{n}$ & 32 & 5 & 268 & 15 \\
\hline Female, n (\%) & $\begin{array}{c}10 \\
(31.25 \%)\end{array}$ & $1(20 \%)$ & $148(55.22 \%)$ & $10(66.66 \%)$ \\
\hline $\begin{array}{l}\text { Age of disease onset, } \\
\text { mean } \pm S D \text { years }\end{array}$ & $\begin{array}{c}7.19 \\
\pm 3.68\end{array}$ & $\begin{array}{c}5.60 \\
\pm 4.93\end{array}$ & $4.91 \pm 3.40$ & $4.93 \pm 3.32$ \\
\hline $\begin{array}{l}\text { Age at study, mean } \\
\pm \text { SD years }\end{array}$ & $\begin{array}{r}14.84 \\
\pm 3.70\end{array}$ & $\begin{array}{l}13.40 \\
\pm 1.67\end{array}$ & $12.51 \pm 4.43$ & $10.73 \pm 3.57$ \\
\hline $\begin{array}{l}\text { Family History of FMF, } n \\
(\%)\end{array}$ & $\begin{array}{c}15 \\
(46.87 \%)\end{array}$ & $1(20 \%)$ & $132(49.25 \%)$ & $6(40 \%)$ \\
\hline $\begin{array}{l}\text { Colchicine resistance in } \\
\text { FMF patients, } n(\%)\end{array}$ & $2(6.25 \%)$ & 0 & $14(5.22 \%)$ & $1(6.66 \%)$ \\
\hline M694V mutation $\mathrm{n}(\%)$ & $19 / 30$ & $3(60 \%)$ & $148 / 245(60.40 \%)$ & $11(73.33 \%)$ \\
\hline Homozygote, $n(\%)$ & (63.33\%) & 2 & $51(34.45 \%)$ & $8(72.72 \%)$ \\
\hline Heterozygote, $n(\%)$ & 7 & $(66.66 \%)$ & $54(36.48 \%)$ & $2(18.18 \%)$ \\
\hline $\begin{array}{l}\text { Compound heterozygote, } \\
\mathrm{n}(\%)\end{array}$ & $\begin{array}{c}(36.84 \%) \\
5\end{array}$ & $\begin{array}{c}1 \\
(33.33 \%)\end{array}$ & $\begin{array}{c}43(29.05 \%) \\
23(8.58 \%)\end{array}$ & $\begin{array}{c}1(9.09 \%) \\
0\end{array}$ \\
\hline $\mathrm{NA}, \mathrm{n}(\%)$ & $\begin{array}{c}(26.31 \%) \\
7 \\
(36.84 \%) \\
2(6.25 \%)\end{array}$ & $\begin{array}{l}0 \\
0\end{array}$ & & \\
\hline $\begin{array}{l}\text { Disease onset over } \\
6 \text { years, } \\
\text { n (\%) years }\end{array}$ & $\begin{array}{c}26 \\
(81.25 \%)\end{array}$ & $5(100 \%)$ & & $6(40 \%)$ \\
\hline Oligorthritis, $n(\%)$ & $\begin{array}{c}21 \\
(65.62 \%)\end{array}$ & $1(20 \%)$ & & 14 (93.33\%) \\
\hline $\begin{array}{l}\text { Inflammatory back pain, } \\
\mathrm{n}(\%)\end{array}$ & $\begin{array}{c}17 / 32 \\
(53.12 \%)\end{array}$ & $\begin{array}{c}3 / 5 \\
(60 \%)\end{array}$ & & 0 \\
\hline Enthesopathy & $\begin{array}{c}22 / 32 \\
(68.75 \%)\end{array}$ & $\begin{array}{c}3 / 5 \\
(60 \%)\end{array}$ & & 0 \\
\hline Sacroiliitis & $\begin{array}{c}14 / 21 \\
(66.66 \%)\end{array}$ & $0 / 1(0)$ & & $0 / 5(0)$ \\
\hline
\end{tabular}

Conclusions: Articular involvement compatible with JSpA could be seen in childhood FMF patients. Spondyloarthropathy was detected in $10 \%$ of childhood FMF cases. The M694V mutation is the most common MEFV mutation among JSpA patients with FMF. JSpA should be considered in childhood FMF patients, especially in those chronic arthritis, axial involvement and enthesopathy.

REFERENCE:

[1] Adrovic A, Sezen M, Barut K, et al. The performance of classification crite ria for juvenile spondyloarthropathies. Rheumatol Int 2017;37:2013-2018.

Disclosure of Interest: None declared

DOI: 10.1136/annrheumdis-2018-eular.3419 


\section{THU0269 DEVELOPMENT OF ANKYLOSING SPONDYLITIS IN PATIENTS WITH REACTIVE ARTHRITIS AND PERIPHERAL SPONDYLOARTHROPATHY: HOSPITAL BASED STUDY IN NORTH INDIA}

R. Misra, S. Ahmed, A. Chaudhury, A. Lawrence, V. Agarwal, A. Aggarwal. Clinical Immunology, Sanjay Gandhi Post Graduate Institute of Medical Sciences, Lucknow, India

Background: Reactive arthritis $(\operatorname{Re} A)$ is a seronegative spondyloarthropathy $(\mathrm{SpA})$ that is precipitated by urogenital or gastrointestinal infection. Undifferentiated Peripheral spondyloarthropathy (UpSpA) may be indistinguishable from $\operatorname{ReA}$ except known preceding infection. It is stated that two-thirds of ReA resolve within three months while a third develop chronic or recurrent course. However, there is a paucity of data on the long-term outcome. Thus, it is difficult to justify treatment decisions like the use of biologicals in $\operatorname{ReA}$

Objectives: To determine the outcome of ReA/upSpA patients attending a referal rheumatology centre in North India.

Methods: ReA was classifed as per Braun's criteria, while UpSpA were included as meeting ASAS criteria but not criteria for psoriatic arthrtis or inflammatory bowel disease associated arthritis. Data on this retrospective cohort was updated with telephonic interviews. Follow-up of less than 1 year were excluded. Patients with persistent inflammatory back pain (IBP) were reviewed in the clinic. Radiographs assessed progression to AS (modified New York criteria).

Results: Follow-up data on 85 patients ( $63 \mathrm{ReA} ; 22 \mathrm{pSpA}$ ) was obtained. Median (IQR) age at presentation was $24.5(20-33)$ years. $14(16.5 \%)$ were female. At presentation, $23(30 \%)$ had monoarthritis, $44(57 \%)$ had oligoarthritis, $10(13 \%)$ had polyarthritis (data missing for eight). Enthesitis and dactylitis were documented in 20 and 5 respectively. Keratoderma and balanitis were seen in one each. $40(80 \%)$ out of 50 were positive for HLA-B27.

Median (IQR) follow-up was 2 (1-5.25) years. 22 had monophasic illness of which 13 had acute arthritis $(<12$ weeks). Seven had two episodes, 27 had polycyclic course while 29 had persistent arthritis. 26 had inflammatory back pain (IBP) at any time and eight had persistent symptoms. Out of these, three (3.5\%) met criteria for AS (disease duration: 1, 3 and 10 years) while two had unilateral grade 2 sacroilitis. Three patients without IBP also had sacroilitis on radiographs. Logistic regression revealed no significant parameter that could predict progression to AS Conclusions: In contrast to general opinion that two thirds attend remission, this study showed that one third undergo drug free remisson. Of the remaining, half deveop recurrent and half persistent arthritis. 3.5\% progressed to AS. As duration of follow-up increases, a greater proportion may progress to AS.

\section{REFERENCES:}

[1] Brinster A, Guillot X, et al. Evolution over thirty years of the profile of inpatients with reactive arthritis in a tertiary rheumatology unit. Reumatol. Clin 2016.

[2] Leirisalo-Repo M, et al. Long-term prognosis of reactive salmonella arthritis. Ann. Rheum. Dis 1997:56,516-520.

[3] Kaarela K, et al. Similarity between chronic reactive arthritis and ankylosing spondylitis.A 32-35-year follow-up study. Clin. Exp. Rheumatol 2009;27:325-328

Disclosure of Interest: None declared

DOI: 10.1136/annrheumdis-2018-eular.6558

\section{THU0270 THE PROPENSITY TO FAT METAPLASIA OF SACROILIAC JOINT IN SPONDYLOARTHROPATHY: RESULTS FROM THE SINGLE REGIONAL CENTRECOHORT}

S.Y. Lee, S.W. lee, W.T. chung, J.W. jung. Rheumatology Of Internal Medicine, Dong-a University Hospital, Pusan, Korea, Republic of Ireland

Background: The predictor of radiographic spinal progression is the presence of syndesmophytes at baseline in axial spondyloarthritis (axSpA) and fat metaplasia on spine maybe predict the formation of new syndemophytes. Some studies suggests that fat metaplasia maybe a potential starting point for new bone formation and have a general systemic effect on new bone formation in spine, rather than results from local inflammation. Recent studies suggest that fat metaplasia on sacroiliac joint (SIJ) MRI at baseline is associated with spinal radiographic progression in axSpA patients.

Objectives: So in this study, we investigated for propensity to fat metaplasia on SIJ in axSpA patients.

Methods: The 357 patients who fulfilled the ASAS axSpA criteria were enrolled. All underwent MRI on Slj with T2 MR image, T1 fat suppressed with enhanced and short $\mathrm{T}$ inversion recovery (STIR) image at baseline and lumbar spine radiographs at baseline and after 2 years. Inflammatory and structural lesions on SIJ MRI was scored using the SPondylo Arthritis Research Consortium of Canada (SPARCC) method. spinal radiographs were scored using the Stoke AS Spina Score (SASSS). Multivariate logistic regression analysis was performed to identify for propensity to fat metaplasia on SIJ in axSpA patients.

Results: Among the 357 patients on baseline SIJ MRI finding, 182 patients showed fat metaplasia on SIJ, 148 patients showed erosion and 27 patients showed ankylosis. Propensity to fat metaplasia in axSpA patients showed the male, HLA-B27 negative, smoking, back pain onset time within 6-12 months at time of diagnosis, uveitis, peripheral arthritis, compared to erosion and anylosis on SIJ in axSpA patients. The patient with fat metaplasia or ankylosis on SIJ at baseline showed increased SASSS but there was no significant change in SPARCC over 2 years. univariate logistic regression analysis showed back pain onset time within 6-12 months at time of diagnosis and uvitis as a significant predictors of fat metaplasia. multivariated logistic analysis showed back pain onset time within 6-12 months at time of diagnosis as an affecting factor for fat metaplasia on SIJ (OR,5.67; 95\% Cl 4.71-17.95).

Abstract THU0270 - Table 1. The radiographic spinal progression over 2 years according to structural lesion in the sacroiliac joints observed on baseline MRI

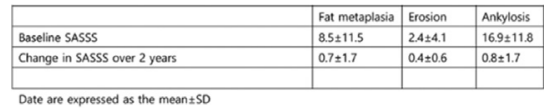

Abstract THU0270 - Table 2. Univariate and multivariate analysis of affecting factor for fat metaplasia on SIJ

\begin{tabular}{|c|c|c|c|c|}
\hline \multirow{2}{*}{ variables } & \multicolumn{2}{|c|}{ univariated analysis } & \multicolumn{2}{|c|}{ Multivariated analysis } \\
\hline & OR(95\%) & p-value & OR(95\%) & p-value \\
\hline $\begin{array}{l}\text { Age at time of } \\
\text { diagnosis (years) }\end{array}$ & $1.10(1.05-1.15)$ & 0.04 & & \\
\hline HLA-B27 positive & $0.28(0.09-0.94)$ & 0.07 & & \\
\hline Smoking & $0.38(0.15-0.98)$ & 0.06 & & \\
\hline $\begin{array}{l}\text { Back pain within } \\
\text { 6-12months at } \\
\text { time of diagnosis }\end{array}$ & 3.12(0.89-10.91) & 0.02 & $5.67(4.71-1795)$ & 0.03 \\
\hline weetis & $259(1.04-6.44)$ & 0.03 & $2.00(0.47-8.62)$ & 0.07 \\
\hline BASOIA & $1.45(0.89-2.78)$ & 0.05 & & \\
\hline $\begin{array}{l}\text { Peripheral } \\
\text { arthritis }\end{array}$ & $0.32(0.10-1.00)$ & 0.06 & & \\
\hline Elevated ESR & $2.59(1.04-6.44)$ & 0.06 & & \\
\hline Elevated CRP & $2.48(1.00-6.19)$ & 0.06 & & \\
\hline
\end{tabular}

Conclusions: The back pain onset time within 6-12 months at time of diagnosis was affecting factor for propensity to fat metaplasia on SIJ in axSpA patients statistically and fat metaplasia on SIJ was associated with radiographic spinal progression in axSpA patients. so the early detection of fat metaplasia on SIJ in axSpA patients was important to protection of radiographic spinal progression.

\section{REFERENCES :}

[1] Maksymowych, et al. MRI evidence of structural changes in thesacroiliac joints of patients with nonradiographicaxial spondyloarthritis even in the absence of MRI inflammation. Arthritis Research \& Therapy 2017;19:126.

[2] Fat Metaplasia on Sacroiliac Joint Magnetic Resonance Imaging at Baseline Is Associated with Spinal Radiographic Progression in Patients with Axial Spondyloarthritis. Plos oneaugust 201513

Acknowledgements: none

Disclosure of Interest: None declared

DOI: 10.1136/annrheumdis-2018-eular.6062

\begin{tabular}{|c|c|c|c|c|c|c|c|}
\hline $\begin{array}{l}\text { Place of study, year of } \\
\text { publication }\end{array}$ & Subjects & $\begin{array}{l}\text { Female: } \\
\text { male }\end{array}$ & Follow up & Remission & Chronic arthritis & $\begin{array}{l}\text { HLA } \\
\text { B27 }\end{array}$ & $\begin{array}{c}\text { Radiological sacroiliitis } \\
\text { (including } \\
\text { asymptomatic) }\end{array}$ \\
\hline France, 20161 & $62 \operatorname{ReA}$ & $10: 52$ & $45 \mathrm{pt} ; 34$ months & $54 \%$ & $\begin{array}{c}44 \% \text { SpA; } 4 \% \\
\text { PsA }\end{array}$ & $64.3 \%$ & NA \\
\hline Finland, 19972 & $\begin{array}{c}63 \text { reactive salmonella } \\
\text { arthritis }\end{array}$ & $28: 35$ & $50 \mathrm{pt}$; mean 11 years & $\begin{array}{l}\text { Drug free: } \\
31.7 \%\end{array}$ & $28.5 \%$ & $88 \%$ & $13.6 \%$ \\
\hline Helsinki, $2009^{3}$ & $60 \mathrm{ReA}$ & $26: 34$ & 40 at 32 years & $\mathrm{HAQ} 0$ in $15 \%$ & NA & $85 \%$ & $15 \%$ \\
\hline Current study & $61 \mathrm{ReA} / 14 \mathrm{uSpA}$ & $14: 71$ & $\begin{array}{l}85 \mathrm{pt} ; \text { median } \\
2 \text { years }\end{array}$ & Drug free: $35 \%$ & $34 \%$ & $80 \%$ & $8.23 \%$ \\
\hline
\end{tabular}

